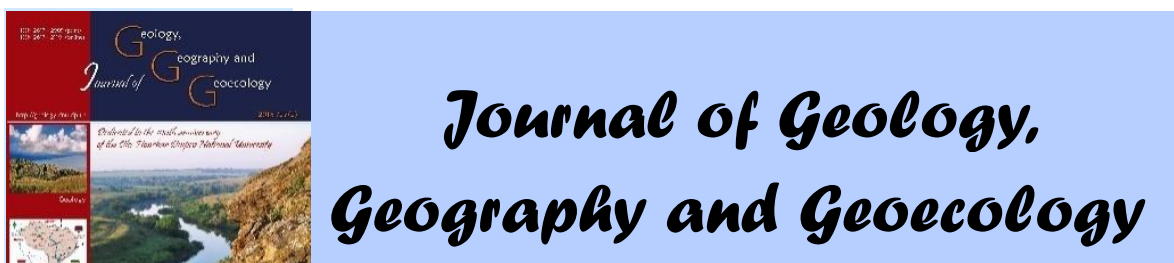

Journal home page: geology-dnu-dp.ua
Journ.Geol.Geograph.

Geoecology, 28(1), 106-113 doi: $10.15421 / 111912$

Lazreg Benaichata, Mahmoud Houari, Mhamed Maatoug,

Mohamed Azzaoui, Naceur Khadidja

Journ.Geol.Geograph.Geoecology, 28(1), 106-113

\title{
Identification of rainfall onset for meteorological use regarding to region in the Algerian highlands
}

\author{
Lazreg Benaichata ${ }^{1}$, Mahmoud Houari ${ }^{2}$, Mhamed Maatoug ${ }^{1}$, Mohamed Azzaoui ${ }^{3}$, Naceur Khadidja ${ }^{1}$, \\ ${ }^{1}$ Ibn Khaldoun university, BPP78 Zaâroura 14000, Tiaret, Algeria,, e-mail: 1lbb55@yahoo.com \\ ${ }^{2}$ National Office of Meteorology, Oran.Algeria,e-mail: mahmoud_haouari@yahoo.fr \\ ${ }^{3}$ Higher Agronomic School of Mostaganem, 27000, Kharouba - Mostaganem, Algeria, e-mail: moha- \\ 1500@outlook.com
}

Received 15.11.2018;

Received in revised form 11.12.2018;

Accepted 28.01.2019

Abstract. The data from several weather stations in Western Algeria show a semi-arid climate during last decades. The entire study region showed a great variability in the occurrences of the first and second rainy days in the year. This variability is associated with a positive trend, showing a continuous increasing aridity in the south Mediterranean and the late arrival of the rainy season is well marked. The rainy season in the north of Algeria, spreads from September to June. The origin of the rains differ according to the seasons. The rainfall from June to October is of localized stormy origin, whereas in winter, the rainfall comes from the classical atmospherically perturbations arriving from North or North West.

This work objective was to give a definition of the rainy season onset and to show its inter - annual variability according to the Niño and Niña years. The El - Niño phenomenon by its positive and negative phases seems to affect the start of the rainy season. The variability of the rainfall onset indices is very significant. There is a relative stability of the rainy season length over the long term period. A significant delay in the precipitation onset was observed during certain years. A method to define rainy season onset based on daily rainfall data from a weather station in the Algerian highlands was proposed. This approach is based on a climatic point of view, using a frequency analysis of precipitation and dates of their first occurrence. It delays the first heavy rain day $(20 \mathrm{~mm}) \mathrm{when}$ La - Niña settles. If EL-Niño settles, the first heavy rain $(20 \mathrm{~mm})$ day will be earlier. These results will improve the probabilistic forecasts of the beginning of the rainy seasons, the cessation as well as the lengths. This work is a preliminary confirmation that the El-Niño phenomenon really affects the Mediterranean climate.

Keywords: meteorology, weather, El-Niño, rainfall, forecast

\section{Виявлення початку випадання опадів для метеорологічного використання в регіоні алжирського нагір'я}

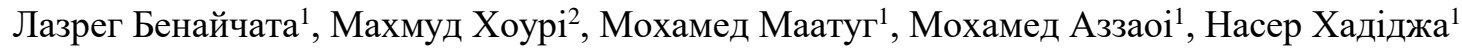 \\ ${ }^{1}$ Університет Ібн Халдун, ВРР78 Задроура 14000, Tiapem, Алжир,, e-mail: llbb55@yahoo.com \\ ${ }^{2}$ Національний офіс Метеорологї, Оран, Алжир, е-таil: mahmoud haouari@yahoo.fr
}

Анотація. Дані декількох метеостанцій на заході Алжиру демонструють напівзасушливий клімат останніх десятиріч. Повномасштабне дослідження регіону засвідчило велику мінливість у проявах першого і другого дощових днів на протязі року. Ця мінливість пов'язана з позитивною тенденцією, що свідчить про постійне підвищення посушливості в південному Середземномор'ї і про пізній наступ сезону дощів. Сезон дощів на півночі Алжиру, поширюється 3 вересня по червень. Походження дощів розрізняється в залежності від сезону. Опади з червня по жовтень мають локальне штормове походження, в той час як взимку опади надходять 3 класичних атмосферних збурень, що прибувають 3 Півночі або 3 північного Заходу. Мета цієї роботи полягала в тому, щоб надати визначення початку сезону дощів і показати його щорічну мінливість в залежності від років Ель Ніньо і Ла Нінья. Явище Ель - Ніньо своїми позитивними і негативними фазами позначається на початку сезону дощів. Варіабельність показників початку дощів дуже значна. Існує відносна стабільність тривалості сезону дощів в довгостроковій перспективі. В окремі роки спостерігалася значна затримка початку випадання 
опадів. Виходячи з даних про щоденні опади, отриманих з метеостанції в алжирському нагір'ї, був запропонований метод визначення початку сезону дощів. Такий підхід заснований на кліматичній точці зору, з використанням частотного аналізу опадів і дат їх першої появи. Варіабельність показників початку дуже значна. Це затримує перший день сильного дощу (20 мм), коли позначається Ла - Нінья. Якщо позначається Ель-Ніньо, то перший сильний дощ (20 мм) випадає на добу раніше. Ці результати дозволять поліпшити імовірнісні прогнози початку, припинення, а також тривалості сезону дощів.

Ключові слова : метеорологія, погода, Ель-Ніньо , опади, прогноз

Introduction. Knowing the beginning and end dates of the rainy season has always been a crucial issue in many parts of the world, especially countries whose agriculture depends on rainfall. A great number of works have been done on this subject for sub-Saharan and part of tropical Africa (Dodd and Joliffe, 2001; Camberlin and Diop, 2002, Balme et al., 2005). The question was not important for our regions because the crop sowing dates in the South Mediterranean were quite well mastered. This old practices was valid until the last observed fluctuations and climatic trends (Benaichata et al., 2016). However this work begins to reveal variability in the start of the rainy season. This observed disturbance of the rainy season is not without effects on crop productivity (Seck et al., 2005). During recent years it was fixed a large variability of rainfed crops yields in several regions (Essotalani et al., 2010). Naturally, these yields are well correlated with the annual rainfall variability (Marteau et al., 2010, Marega, 2016.). Hence there is an interest in knowing the dates of the beginning of the rainy season. The methods for determining these dates can be considered, from the agronomic, hydrological and atmospheric point of view by considering the installation of the meteorological action centres and the arrival of different meteorological perturbation types. It was defined the beginning of the rainy season as the first occurrence of $20 \mathrm{~mm}$ of rain in 2 consecutive days for the sub-Saharan regions (Stern, 1982). However, in Mediterranean region and especially in regions with arid and semi-arid climates, rains usually last less than 5 days with low intensities. The criteria applicable to sub-Saharan regions are not valid for our regions. This study is much more interested in the installation of the rainy season for the benefit of cereals and the criteria for the onset of the rainy season are based in this case on the analysis of a survey filled by farmers in the highland region of western Algeria. Several works are carried out in this direction for the sub-Saharan regions (Benoit, 1977; Cook and Heerdegen, 2001). One case study has been done for the Mediterranean regions with the exception of a synthesis (Aviad et al. 2004).The farmers of the Mediterranean regions did not worry about the variability of the rainy season onset and work with inherited dates of sowing. At the same time the rainy season length is important in sub-Saharan regions. All the definitions used for West Africa were summarized with Fitzpatrick et al. (2015). According to Belaid (1996) and depending to the agro-climatic zone, the optimum sowing period is between 15 October and 15 November. However, following a survey analysis, we found that after the 2000s, they observed late dates of onset. Hence there is a need to study the variability of these onset dates. The determination of the beginning of the rainy season was based on (I) the occurrence and cumulative precipitation in three days after $1^{\text {st }}$ September, (II) the number of days without rain between these first three days of rain and (III) the day where the cumulative rainfall amounted is equal to $20 \mathrm{~mm}$. The example taken here is the for Tiaret weather station $(35.34 \mathrm{~N}, 1.46 \mathrm{E})$. It is known that El Niño - southern oscilation (ENSO) is the dominant mode of variability over the Pacific Ocean and effects the sources of fresh water upon which millions of people rely (Curtis, 2008; Trenberth and Hoar, 1997). El Niño and La Niña event cause droughts and floods over different parts of the globe and have strong impact on the economies of the countries they affect (Hapuarachchi and Jayawardena, 2015). The objective of this work was to give a definition of the rainy season onset and to show its inter annual variability according to the Niño and Niña years.

Materials and methods. In this study, we used archived data from international centres that collect hourly data transiting, through the Global Telecommunication System (GTS). Even though these data are not fully controlled or corrected before being transmitted in messages (METAR and SYNOP), we have found that they are acceptable for our study. To achieve this work, more than 30 years (1990-2017) daily data are downloaded from the National Oceanic and Atmospheric Administration (NOAA) website (www7.ncdc.noaa.gov/CDO/cdo). As already mentioned above, the first months of the rainy season have seen a great inter-annual variability with high coefficients of variation values and slopes signs changes (Fig.1). 
Tiaret Precipitation (Sep), CV $=130 \%$

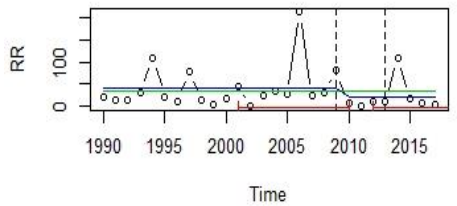

Tiaret Precipitation (Nov), CV $=98 \%$

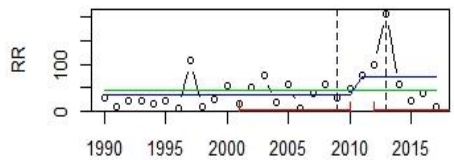

Time

Fig. 1. Changes in precipitation of SOND months

The rainy season in the north of Algeria, spreads from September to June where the origin of the rains differ according to the seasons. The rainfall from June to October is of localized stormy origin, whereas in winter, the rainfall comes from the classical atmospherically perturbations arriving from North or North West. Climate data are available mainly in meteorological services for researchers at excessive prices. We considered only

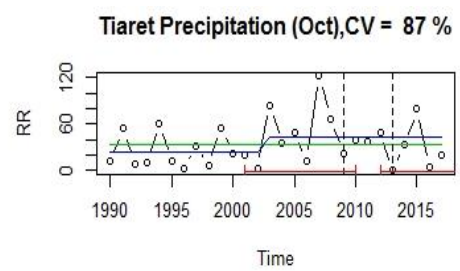

Tiaret Precipitation $(\mathrm{Dec}), \mathrm{cv}=, \mathrm{CV}=76 \%$

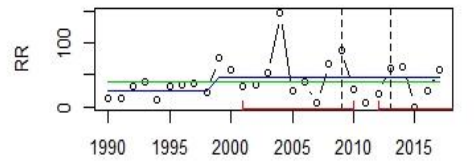

Time

the months starting from September to December to determine the beginning of the rainy season. The rainy season is installed only if the daily precipitation has exceeded a rainfall threshold $(0.1$ $\mathrm{mm})$. The number of days without rain between the first three rainy days does not exceed 15 days and that the cumulative rainfall has exceeded $20 \mathrm{~mm}$.

Results and discussion. The amounts of daily precipitation are set out in the Table 1 .

Table 1. Tiaret daily rainfall in 2015 (Data Source: NOAA)

\begin{tabular}{|c|c|c|c|c|c|c|c|c|c|c|c|c|}
\hline Days & Jan & Feb & Mar & Apr & May & Jun & Jul & Aug & Sep & Oct & Nov & Dec \\
\hline 1 & $*$ & 14.9 & $*$ & $*$ & $*$ & $*$ & $*$ & $*$ & $*$ & $*$ & $*$ & $*$ \\
\hline 2 & $*$ & $*$ & $*$ & $*$ & $*$ & 1.02 & $*$ & $*$ & $*$ & $*$ & 7.11 & $*$ \\
\hline 3 & $*$ & 0.25 & $*$ & $*$ & $*$ & $*$ & $*$ & $*$ & 11.94 & $*$ & 1.02 & $*$ \\
\hline 4 & $*$ & 3.05 & $*$ & $*$ & $*$ & 7.11 & $*$ & $*$ & $*$ & $*$ & $*$ & $*$ \\
\hline 5 & $*$ & 5.08 & $*$ & $*$ & $*$ & 5.08 & $*$ & $*$ & $*$ & $*$ & $*$ & $*$ \\
\hline 6 & $*$ & 4.06 & $*$ & $*$ & $*$ & $*$ & $*$ & $*$ & $*$ & $*$ & $*$ & $*$ \\
\hline 7 & * & 1.02 & $*$ & $*$ & $*$ & * & $*$ & $*$ & $*$ & $*$ & $*$ & $*$ \\
\hline 8 & $*$ & 4.06 & $*$ & $*$ & $*$ & $*$ & $*$ & $*$ & $*$ & 14.99 & $*$ & $*$ \\
\hline 9 & $*$ & $*$ & $*$ & $*$ & $*$ & $*$ & $*$ & $*$ & $*$ & 26.92 & $*$ & $*$ \\
\hline 10 & $*$ & $*$ & $*$ & $*$ & $*$ & 1.02 & $*$ & $*$ & $*$ & 1.02 & $*$ & $*$ \\
\hline 11 & $*$ & $*$ & $*$ & $*$ & $*$ & $*$ & $*$ & 2.03 & $*$ & $*$ & $*$ & $*$ \\
\hline 12 & $*$ & $*$ & $*$ & $*$ & $*$ & $*$ & $*$ & $*$ & $*$ & $*$ & $*$ & $*$ \\
\hline 13 & $*$ & $*$ & $*$ & $*$ & $*$ & $*$ & $*$ & $*$ & $*$ & $*$ & $*$ & $*$ \\
\hline 14 & $*$ & 2.03 & $*$ & $*$ & $*$ & 1.02 & $*$ & $*$ & $*$ & 6.10 & $*$ & $*$ \\
\hline 15 & $*$ & 0.25 & $*$ & $*$ & $*$ & $*$ & $*$ & $*$ & $*$ & $*$ & $*$ & $*$ \\
\hline 16 & $*$ & 7.87 & $*$ & $*$ & $*$ & $*$ & $*$ & $*$ & $*$ & $*$ & $*$ & $*$ \\
\hline 17 & 0.51 & 2.03 & $*$ & $*$ & $*$ & $*$ & $*$ & $*$ & $*$ & $*$ & $*$ & $*$ \\
\hline 18 & 1.02 & 3.05 & $*$ & $*$ & $*$ & $*$ & $*$ & $*$ & $*$ & 3.05 & $*$ & $*$ \\
\hline 19 & 2.03 & 0.2 & $*$ & $*$ & $*$ & 0.25 & $*$ & $*$ & $*$ & $*$ & $*$ & $*$ \\
\hline 20 & 7.87 & $*$ & $*$ & 0.51 & $*$ & $*$ & $*$ & $*$ & $*$ & $*$ & $*$ & $*$ \\
\hline 21 & 2.03 & 7.87 & $*$ & $*$ & $*$ & $*$ & $*$ & $*$ & $*$ & 2.03 & $*$ & $*$ \\
\hline 22 & 9.91 & 9.91 & 2.03 & $*$ & $*$ & $*$ & $*$ & 7.11 & $*$ & 13.97 & 8.89 & $*$ \\
\hline 23 & 2.03 & 2.03 & $*$ & $*$ & $*$ & $*$ & $*$ & $*$ & $*$ & $*$ & 0.51 & $*$ \\
\hline 24 & $*$ & $*$ & $*$ & $*$ & 2.03 & $*$ & $*$ & $*$ & $*$ & $*$ & $*$ & $*$ \\
\hline 25 & $*$ & 2.03 & 2.03 & $*$ & 7.11 & $*$ & $*$ & $*$ & $*$ & 3.05 & 2.03 & $*$ \\
\hline 26 & $*$ & 2.03 & 5.08 & $*$ & 5.08 & $*$ & $*$ & 0.51 & $*$ & 0.51 & $*$ & $*$ \\
\hline 27 & $*$ & 3.05 & 2.03 & $*$ & $*$ & $*$ & $*$ & $*$ & $*$ & 7.87 & $*$ & $*$ \\
\hline 28 & $*$ & 6.10 & $*$ & $*$ & $*$ & $*$ & $*$ & $*$ & $*$ & $*$ & 2.03 & $*$ \\
\hline 29 & $*$ & $*$ & $*$ & $*$ & 0.76 & $*$ & $*$ & $*$ & $*$ & $*$ & $*$ & $*$ \\
\hline 30 & $*$ & & $*$ & $*$ & 0.76 & $*$ & $*$ & $*$ & 6.10 & $*$ & $*$ & $*$ \\
\hline 31 & $*$ & & $*$ & & $*$ & & $*$ & & $*$ & $*$ & & $*$ \\
\hline
\end{tabular}


The stars represent the days without rain and the values are the daily amount of precipitation in millimetres. This table is an example of daily precipitation datasets (year 2015). We see that the first day of a quantifiable rainfall amount $(\geq 0.1 \mathrm{~mm})$ corresponds to September $3^{\text {rd }}$.

The first day exceeding $10 \mathrm{~mm}$ matches with the first day of rain. The first day of rain exceeding $20 \mathrm{~mm}$ corresponds to October 09 th.
The day where the cumulative rainfall exceeding $20 \mathrm{~mm}$ coincides with October $08^{\text {th }} 2015$ year.

There is more than 20 dry days between the first and the second rainy days. We guess that the first rainy day does not correspond to the beginning of the rainy season and can't be considered in the $20 \mathrm{~mm}$ cumulating.

In our example the rainy season started on the $08^{\text {th }}$ or the $09^{\text {th }}$ of October 2015 year (Fig. 2 and 3).

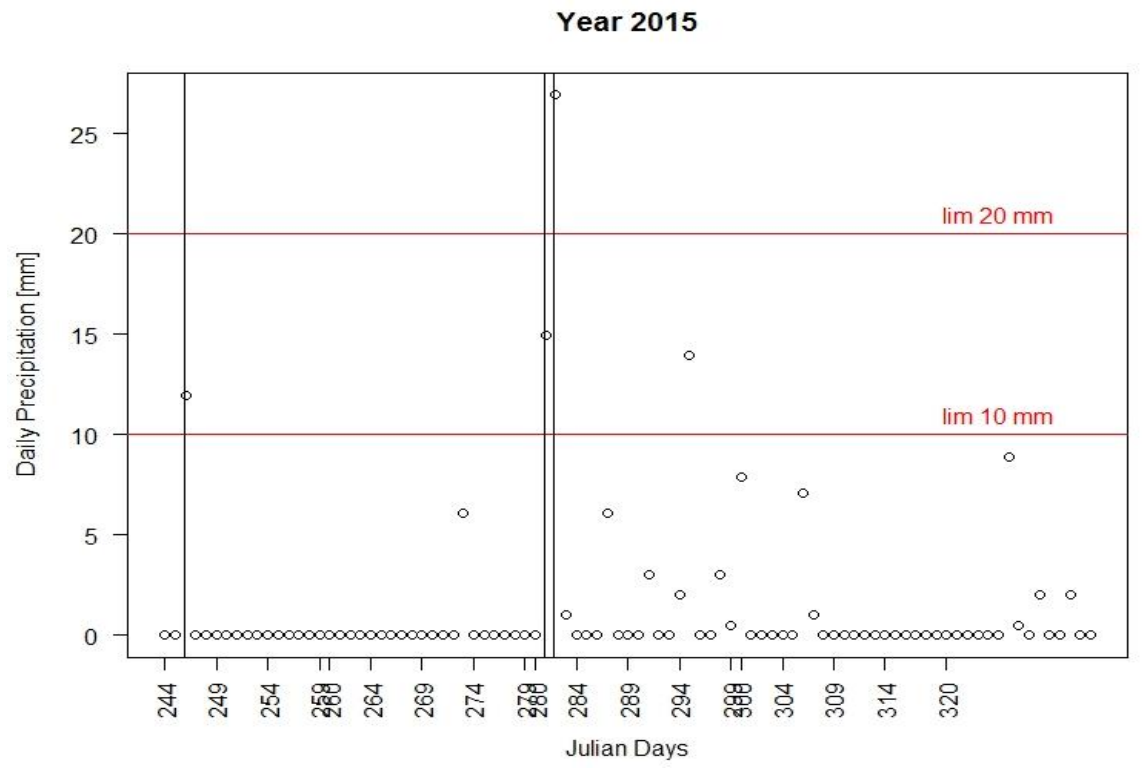

Fig. 2. Illustration of the 10 and $20 \mathrm{~mm}$ thresholds (red horizontal lines)

The black vertical lines correspond to the days and thresholds. Julian days that coincide with the two first rainy

Year 2015

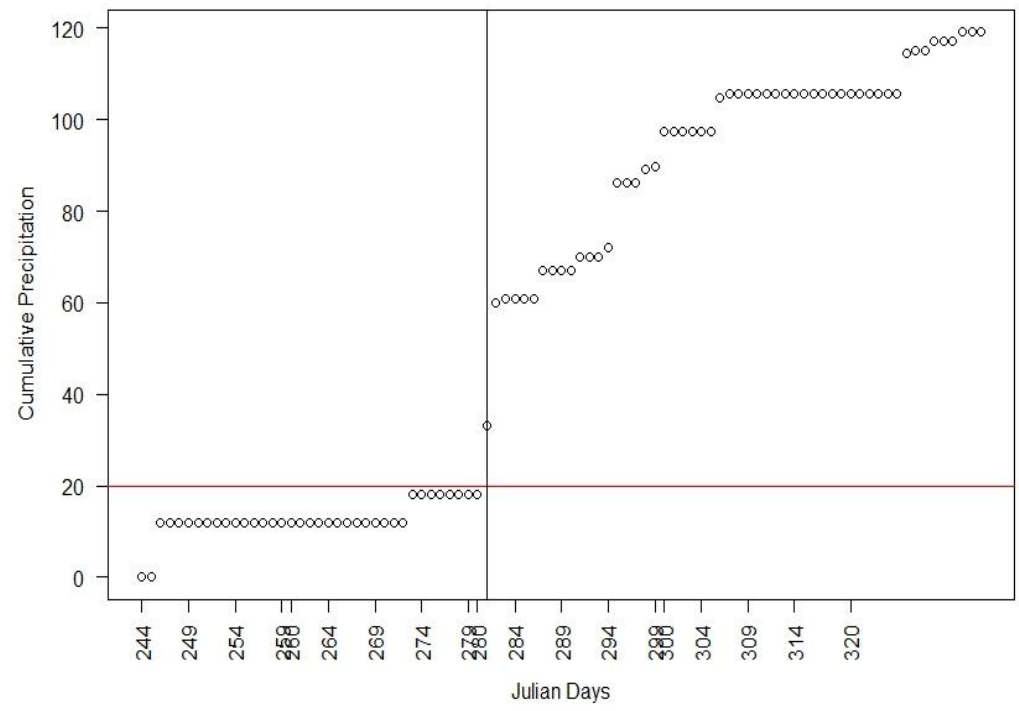

Fig. 3. Illustration of the cumulative $20 \mathrm{~mm}$ thresholds

The black vertical lines correspond to the Julian days that coincide with the threshold (red horizontal line). According to Figure 3 the cumulative $20 \mathrm{~mm}$ correspond to October, $8^{\text {th }}$ (starting of the rainy season).

The dates of occurrence of the first and second rainy days are shown in figures 4 and 5 . 


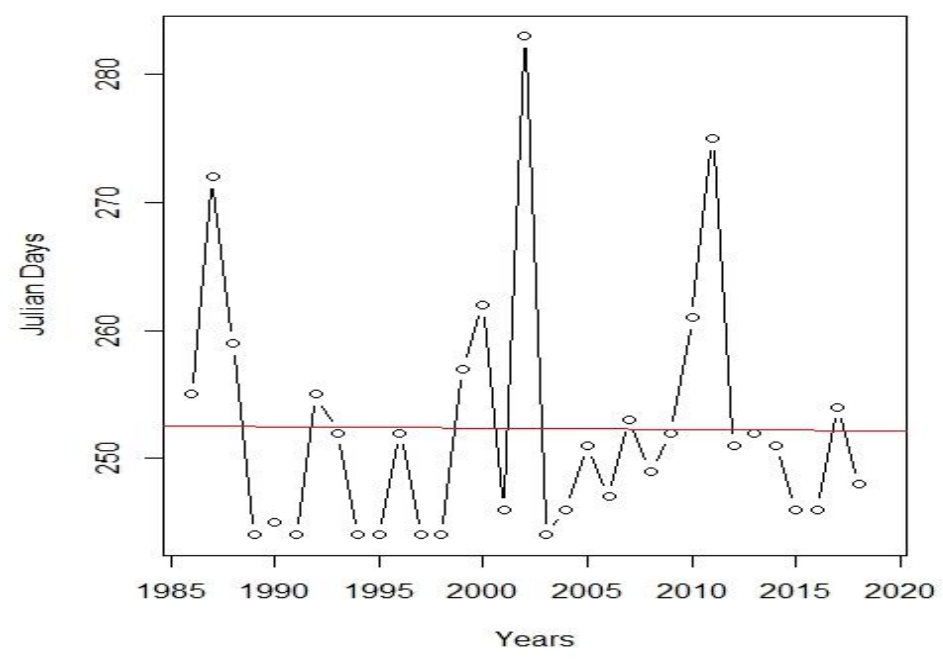

Fig. 4. Dates of occurrence of the first rainy days.

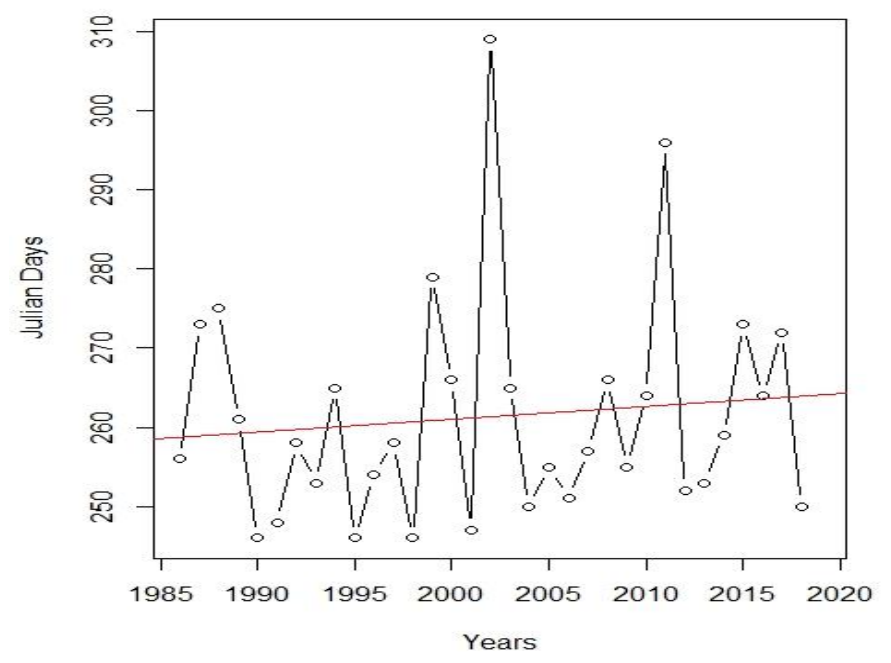

Fig. 5. Dates of occurrence of the second rainy days

The analysis of the curves of the first and second days with measurable amount $(\geq 0.1 \mathrm{~mm})$ shows that there is a great inter-annual variability of these dates. We also found that there is a positive trend of these dates. This trend can be explained by the fact that the onsets of the rainy seasons are later in recent years, confirming the work of Ati et al. (2002). The data on variation of the first cumulative rainfall dates reaching $20 \mathrm{~mm}$ and dry sequences separating the 2 first rainy days are shown in figures 6 and 7.

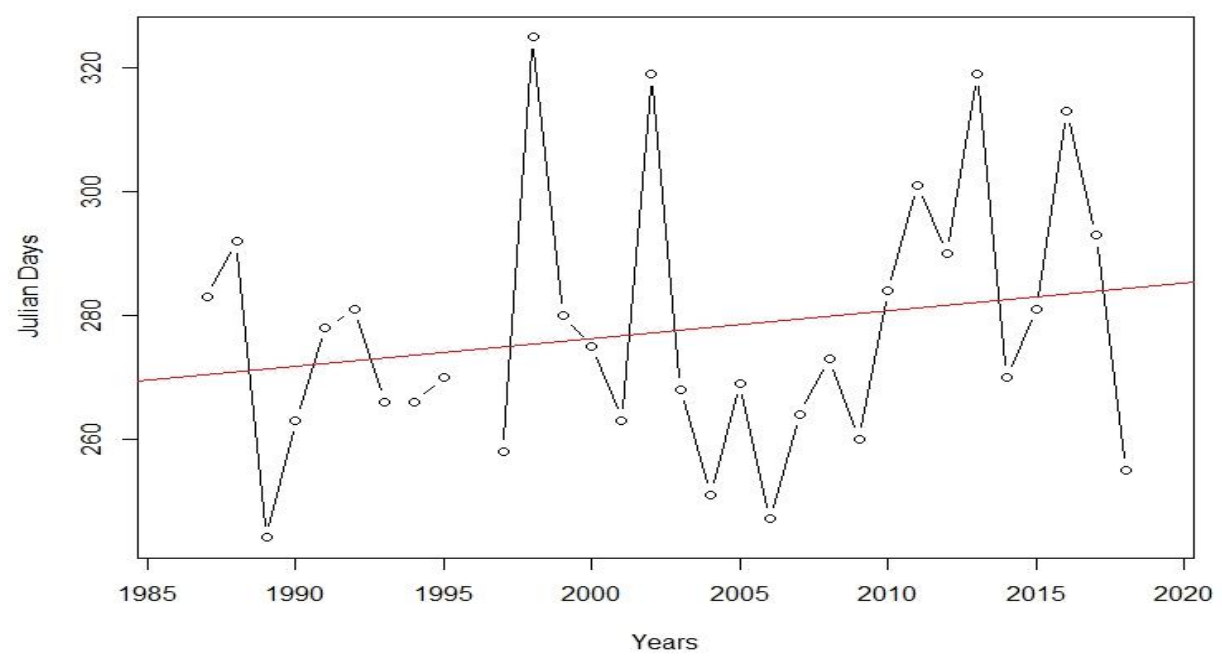

Fig. 6. Variation and trend of the first cumulative rainfall dates reaching $20 \mathrm{~mm}$ 
The interpretation of the curves in fig. 6 and 7 shows the inter-annual variability of the first and second rainy days as well as the positive trend of their regression lines. These figures clearly show a shift after the year 2000, in the beginning of the rainy season.

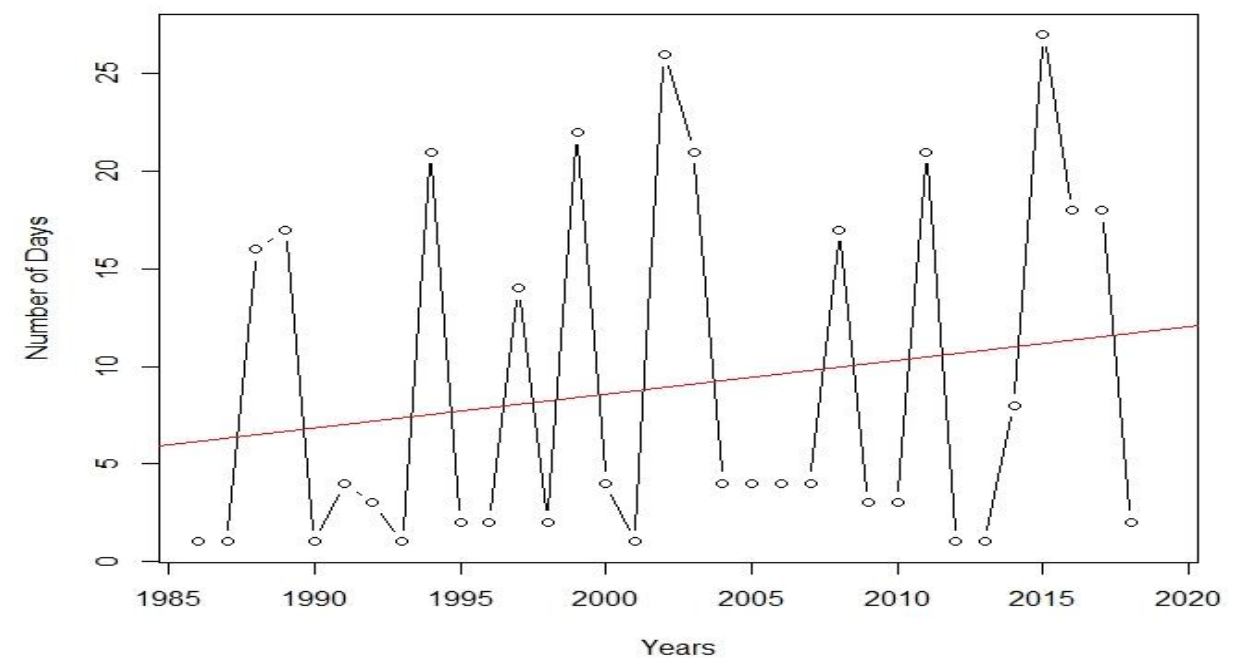

Fig. 7. Variation and trend of the dry sequences separating first and second rainy days.

Fig. 7, explains the time lag to reach a cumulative rainfall amount of $20 \mathrm{~mm}$ at Tiaret weather station. It was shown the increase in the number of false alarms of the annual precipitation onset. This great variability was reported by Reiser and Kutiel (2007).

A logistic regression was used to find a relationship between the beginning of the rainy season and the El-Niño/La-Nina phenomenon,. The logistic regression is widely used in many areas (Adams and Lawrence, 2019).

Other ways use this approach to look for association between onset variability of precipitation and equatorial ocean temperatures
(Joseph, 1994). This analysis aims to explain and predict the values of a dependent variable $\mathrm{Y}$ (starting date of the rainy season), from an independent variable $\mathrm{X}$ representing the Oceanic Niño Index (ONI) modalities (Cornillon et al., 2012).

The ONI index data are available at: http://ggweather.com/enso/oni.htm. Since the ONI index is considered here as an explanatory qualitative variable with 7 modalities (Table 2), we applied a logistic regression to note how modalities and significance of the variable ONI correspond to El Niño and La Nina.

Table 2. Modalities and significance of the variable ONI

\begin{tabular}{|c|c|}
\hline Modality & Signification \\
\hline WE & Weak EI Niño \\
\hline ME & Moderate EI Niño \\
\hline SE & Strong El Niño \\
\hline VSE & Very Strong El Niño \\
\hline WL & Weak La Niña \\
\hline ML & Moderate La Niña \\
\hline SL & Strong La Niña \\
\hline
\end{tabular}

The results for the two explained variables: (1) First $10 \mathrm{~mm}$ precipitation and (II) First $20 \mathrm{~mm}$. Note that other methods are used in the search for remote connections between El niño and climatic parameters (Camberlin et al., 2001).

The logistic regression is applied to the dates of the first rainy day with $10 \mathrm{~mm}$ as a variable to be explained and the ONI index as an explanatory variable. The results obtained from this analysis are grouped in Table 3 using Rlanguage.

According to Table 3, the first yearly days with $10 \mathrm{~mm}$ precipitation are negatively affected by El-Niño and Very Strong El-Niño (WE and VSE) at 5\% significance level. This can be explained as follows: The first rains up to $10 \mathrm{~mm}$ will be relatively early in years when the El Niño phenomenon sets in. 
Table 3. Analysis of the effect of El-Niño phenomenon on the dates of the first rains up to $10 \mathrm{~mm}$ by logistic regression

\begin{tabular}{|c|c|c|c|}
\hline Modality & Estimate \pm std. error & T & value $\operatorname{Pr}(>|\mathrm{t}|)$ \\
\hline (Intercept) & $300.5 \pm 14.3$ & 20.99 & 0.001 \\
\hline ML & $-31.2 \pm 18.5$ & -1.69 & 0.143 \\
\hline SL & $-8.5 \pm 24.8$ & -0.34 & 0.743 \\
\hline VSE & $-48.5 \pm 20.2$ & -2.40 & 0.054 \\
\hline WE & $-47.5 \pm 18.5$ & -2.57 & $0.042^{*}$ \\
\hline WL & $-1.5 \pm 24.8$ & -0.06 & 0.954 \\
\hline
\end{tabular}

The analysis shows that the first days with

rains up to $20 \mathrm{~mm}$ by La-Niña (Table 4) this type of rain is positively affected for the first

Table 4. Analysis of the effect of the El-Niño phenomenon on the dates of the first rains up to $20 \mathrm{~mm}$ by logistic regression.

\begin{tabular}{|c|c|c|c|}
\hline Modality & $\begin{array}{c}\text { Estimate Estimate } \pm \text { std. } \\
\text { error }\end{array}$ & $\mathrm{T}$ & value $\operatorname{Pr}(>|\mathrm{t}|)$ \\
\hline (Intercept) & $271.0 \pm 14.2$ & 19.14 & $<0.001$ \\
\hline ML & $17.0 \pm 20.0$ & 0.85 & 0.4853 \\
\hline SL & $59.0 \pm 20.0$ & 2.95 & 0.0985 \\
\hline VSE & $0.5 \pm 17.3$ & 0.03 & 0.9796 \\
\hline WE & $-14.5 \pm 17.3$ & -0.84 & 0.4911 \\
\hline WL & $61.0 \pm 20.0$ & 3.05 & 0.093 \\
\hline
\end{tabular}

The statistical significance is not proven at $5 \%$ threshold, but can be acceptable at $10 \%$ significant level. If we accept this result it can be

explained by the fact that the first daily heavy rains of $20 \mathrm{~mm}$ are late when La - Niña years is set up.

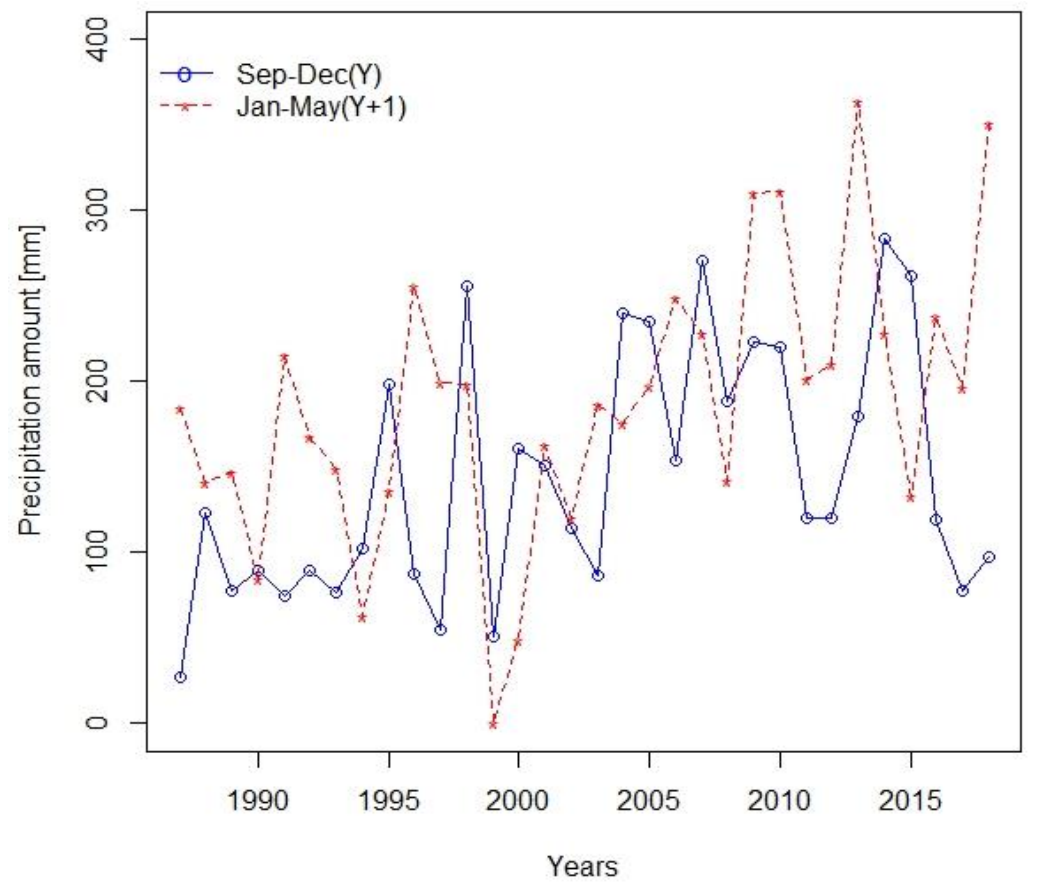

Fig. 8. Deviation of cumulative precipitation between SOND and JFMAM season

The Fig. 8, compares the cumulative rainfall totals for the months from September to December with the months from January to May. We note on this figure that during some years, the cumulative rainfall from January to May exceed the cumulative rainfall from September to December. During these years the start of rainy season are delayed with droughts. This figure suggests in the future to compare this oscillation with the Nino years.

Conclusion. In general, several weather stations in Western Algeria show a semi-arid climate in their data. The entire study region showed a great variability in the occurrences of the first and second rainy days in the year. This variability is associated with a positive trend, showing a 
continuous increasing aridity in the south Mediterranean and the late arrival of the rainy season is well marked. The El - Niño phenomenon by its positive and negative phases seems to affect the start of the rainy season. It delays the first heavy rain day $(20 \mathrm{~mm})$ when La - Niña settles. If EL-Niño settles, the first heavy rain $(20 \mathrm{~mm})$ day will be earlier. These results will improve the probabilistic forecasts of the beginning of the rainy seasons, the cessation as well as the lengths. Note that the bibliography is very rich in terms of definitions of the start and end of rainy seasons but the use of logistic regression is not very widely used in climatology. This work is a preliminary confirmation that the El-Niño phenomenon really affects the Mediterranean climate.

\section{References}

Adams, K.A., Lawrence E.K. 2019. Research Methods, Statistics, and Applications, Sage Publi., Calif. Second Edition. 672 p.

Ati O.F., Stigter C..J., Oladipo E.O. 2002. A comparison of methods to determine the onset of the growing season in Northern Nigeria. International Journal of Climatology 22: 731-742.

Aviad Y., Kutiel H., Lavee H. 2004.Analysis of beginning, end, and length of the rainy season along a Mediterraneen-arid climate transect for geomorphic purposes. Journal of Arid Environments. 59, 189-204.

Balme M., Galle S., Lebel T. 2005. Démarrage de la saison des pluies au Sahel: variabilité aux échelles hydrologique et agronomique, analysée à partir des données EPSAT-Niger. Sécheresse, 16 (1), $15-22$.

Belaid D. 1996. Aspects de la céréaliculture Algérienne. Ed. Office des publications universitaires, BenAknoun (Alger), $206 \mathrm{p}$.

Benaichata L., Mederbal K., Chouieb M. 2015. Climate Change Detection with Extreme Weather Factors Concerning Algeria. ESJ. 11: 220-232.

Benoit, P., 1977. The start of the growing season in northern Nigeria. Agric. Meteorol. 18, 91-99.

Camberlin P. Janicot S., Poccard, I. 2001. Seasonality and atmospheric dynamics of the teleconnection between African rainfall and tropical sea-surface temperature: Atlantic vs. ENSO, International Journal of Climatology, 21(8), 973 - 1005.

Camberlin P., Diop M., 2002. Application of daily rainfall PCA to the assessment of the rainy season characteristics in Senegal. Climate Research.

Cook G.D., Heerdegen R.G., 2001. Spatial variation in the duration of the rainy season in monsoonal
Australia. International Journal of Climatology, 21, 1723 - 1732.

Cornillon P.A., Guyader A., Husson F., Jélou N., Josse J., Kloareg M., Matzner - Lober E., Rouvière L. 2012. Statistiques avec R. Presse Universitaire de Reines.

Curtis S. 2008. The El-Nino southern oscilation and global precipitation. Geogr.Compass, 2, 600-619.

Dodd D.E.S, Joliffe I.T. 2001. Early detection of the start of the wet season in semiarid tropical climates of western Africa. International Journal of Climatology, 121: 1251-1262

Essotalani A., Kossi M., Badameli S., Dubreuil V., 2010. Evolution of rainy seasons potentially useful for Togo on the 1950-2000 period, Climatologie, 89-107.

Fitzpatrick, R.G., Bain, C.L., Knippertz, P., Marsham J.H., Parker, D.J. 2015. The West African monsoon onset : A concise comparison of definitions, Journal of Climate, 28(22), 86738694.

Hapuarachchi H.A.S.U., Jayawardena I.M.S.P. 2015. Modulation of seasonal rainfall in Sri Lanka by ENSO extremes.Sri Lanka Journal.of Meteorology.Vol.1:3-11

Joseph P.V., Eischeid J.K., Pyle R.J., 1994. International variability of the onset of the Indian Summer monsoon and its association with atmospheric features, El Nino, and sea surface temperatures. Journal of Climate, 7: 81-105.

Marega O. 2016. Changements socio-environnementaux et évolution des pratiques agropastorales en Afrique sahélienne: étude comparée entre le Ferlo (Sénégal), le Gourma (Mali) et le Fakara (Niger)», thèse de doctorat, Université Diderot Paris 7, $700 \mathrm{p}$.

Marteau R., Benjamin Sultan B., Moron V., Baron C., Traoré S.B. 2010. Démarrage de la saison des pluies et date de semis du mil dans le sud-ouest $\mathrm{du}$ Niger. XXIIIe colloque de l'Association Internationale de Climatologie. Risques et changement climatique:379-384

Reiser H., Kutiel H. 2007. The rainfall regime and its uncertainty in Valencia and Larnaca. Advances Geosciences, European Geosciences Union,101106.

Seck M., Moussa N.A., Abou M., Wade S., Thomas J.P. 2005. Adaptation aux changements climatiques. L'étude de cas des systèmes de production agricoles de Sébikotane (Sénégal), ENDA TiersMonde, $33 \mathrm{p}$.

Stern, R.D., 1982. Computing a Probability Distribution for the Start of the Rains from a Markov Chain Model for Precipitation. Journal Applied Meteorology, 21, 420-423.

Trenberth K.E.,Hoar T.J. 1997. El Nino and climate change.Geophys.Res. Lett., 24, 3057-3060. 